\title{
Sifat Fisik dan Sensori Flakes Pati Garut dan Kacang Merah dengan Penambahan Tiwul Singkong
}

\section{Physical and Sensory Properties of Arrowroot Starch and Red Beans Flakes with Tiwul Cassava Addition}

\author{
Sussi Astuti*, Suharyono A.S. dan ST Aisah Anayuka \\ ${ }^{1}$ Jurusan Teknologi Hasil Pertanian Fakultas Pertanian Universitas Lampung \\ Jl. Prof. Soemantri Brojonegoro No. 1 Bandar Lampung, Lampung 35145 \\ *E-mail : sussi_astuti@yahoo.com
}

\begin{abstract}
The aim of the study was to evaluate the physical and sensory properties of arrowroot and red bean starch flakes with the addition of tiwul cassava. The research was arranged in a Complete Randomized Design with six replications. The factor was the formulation of arrowroot starch and red beans flour consisted of six levels, i.e. 100\%:0\% (F1); $90 \%: 10 \%$ (F2); 80\% : 20\% (F3); 70\% : 30\% (F4); 60\% : 40\% (F5); dan 50\% : 50\% (F6). The data were analyzed using ANOVA and were tested with the LSD test at a $5 \%$ level of significance. The best formulation was found on flakes produced from $50 \%$ arrowroot starch and $50 \%$ red beans flour (F6) with physic properties (texture) was 1,47 kg, the color score of 2,67 (light brown), the flavor and aroma score of 3,47 (little rotten taste), and the overall acceptance score at 3,87 (like).The best flakes has moisture content of 5,17\%, ash content of 2,81\%, protein content of $11,53 \%$, fat content of $1,25 \%$, carbohydrate content of $79,24 \%$, and crude fiber content of $2,55 \%$.
\end{abstract}

Keywords: arrowroot, flake, red beans, tiwul cassava

Disubmit : 03 Juni 2019; Diterima: 14 Agustus 2019; Disetujui: 28 Oktober 2019

\section{PENDAHULUAN}

Salah satu makanan yang digemari masyarakat sebagai makanan sarapan adalah flakes. Flakes merupakan produk sarapan siap saji yang membutuhkan waktu relatif singkat dalam penyajian dan memenuhi kebutuhan kalori karena mengandung karbohidrat cukup tinggi. Pada umumnya, flakes yang dijual di pasaran terbuat dari serealia atau biji-bijian seperti gandum, jagung, dan beras. Umbi-umbian dan kacang-kacangan dapat digunakan sebagai bahan baku flakes. Perpaduan antara umbi-umbian yang mengandung karbohidrat dengan kacang-kacangan yang merupakan sumber protein dapat digunakan sebagai bahan baku produk flakes yang kaya gizi dan menyehatkan.

Garut (Maranta arundinaceae L.) merupakan salah satu jenis umbi-umbian yang mulai banyak dimanfaatkan oleh masyarakat sebagai bahan pangan. Menurut Mariati (2001), kandungan pati garut sebesar 92,24-98,78\%, amilosa sebesar 29,67-31,34\%, amilopektin sebesar 55,81-69,16\%, sedangkan kadar karbohidrat sebesar $85,61-88,45 \%$. Oleh karena itu, pati garut dapat digunakan sebagai bahan baku produk flakes karena tinggi karbohidrat, namun perlu dikombinasi dengan bahan pangan tinggi protein untuk meningkatkan nilai gizi flakes. 
Kacang merah (Phaseolus vulgaris L.) adalah salah satu jenis kacang-kacangan yang dikenal luas dan dimanfaatkan masyarakat sebagai sumber protein nabati. Kandungan protein kacang merah cukup tinggi, yaitu berkisar 21-27\%. Pemanfaatan kacang merah sebagai sumber protein produk flakes dilakukan untuk penganekaragaman olahan kacang merah dan memperkaya produk flakes yang dihasilkan.

Penambahan tapioka pada pembuatan flakes diperlukan untuk meningkatkan penampilan produk akhir flakes, mengembangkan produk sehingga flakes tidak mudah keras, meningkatkan daya rekat karena kandungan pati yang tinggi, serta menghasilkan tekstur produk yang renyah. Tiwul singkong adalah makanan tradisional khas Indonesia yang banyak diproduksi di Provinsi Lampung. Menurut Hasan et al. (2011), tiwul singkong mengandung karbohidrat sebesar $82,7 \%$, sehingga tiwul singkong dapat dijadikan sebagai pengganti tapioka dalam pembuatan flakes. Penggunaan tiwul singkong diharapkan dapat menghasilkan produk flakes yang kaya gizi dan menyehatkan.

Vijayakumar \& Mohankumar (2009) menyatakan bahwa penambahan berbagai jenis tepung dapat memperbaiki sifat rheologi tepung dan meningkatkan nilai gizi produk yang dihasilkan. Pemanfaatan pati garut, kacang merah, dan tiwul singkong dalam pembuatan flakes dapat digunakan sebagai salah satu pangan alternatif pengganti sarapan. Oleh karena itu, penelitian ini dilakukan untuk mengevaluasi sifat fisik dan sensori flakes pati garut dan kacang merah dengan penambahan tiwul singkong.

\section{METODE PENELITIAN}

Bahan utama adalah pati garut merk Hasil Bumiku dari Yogyakarta, kacang merah dari Pasar Perumnas Way Halim, dan tiwul singkong diperoleh dari salah satu UKM tiwul singkong di Sekampung, Lampung Timur. Bahan tambahan adalah garam halus merk Rafina, gula rendah kalori merk Tropicana Slim, dan air. Bahan kimia untuk analisis adalah $\mathrm{H}_{2} \mathrm{SO}_{4}, \mathrm{~K}_{2} \mathrm{SO}_{4}, \mathrm{NaOH}, \mathrm{Na}_{2} \mathrm{~S}_{2} \mathrm{O}_{3}, \mathrm{H}_{3} \mathrm{BO}_{3}, \mathrm{HCl}, \mathrm{NaOH}$, alkohol, indikator metil merah dan metil biru, dan hexana.

Alat untuk pembuatan flakes adalah timbangan, baskom, wadah plastik, sendok, oven, grinder, mixer, panci pengukus, noodle maker, loyang, ayakan 80 mesh, dan oven pemanggang merk Kirin, sedangkan alat untuk analisis adalah Hardness Tester merk Kiya Seisakusho, Ltd., cawan porselen, desikator, neraca analitik, oven, tanur, penjepit, labu kjeldahl, labu lemak, alat ekstraksi soxhlet, reflux kondensor, kertas saring, alatalat gelas dan seperangkat alat uji sensori.

Penelitian disusun dalam Rancangan Acak Kelompok Lengkap (RAKL) dengan satu faktor yaitu formulasi pati garut dan kacang merah dengan enam taraf perlakuan dan empat ulangan. Perlakuan faktor tunggal yaitu formulasi pati garut dan kacang merah dengan perbandingan 100\%: 0\% (F1); 90\%: $10 \%$ (F2); 80\% : 20\% (F3); 70\% : 30\% (F4); 60\% : 40\% (F5); dan 50\% : 50\% (F6). Data dianalisis sidik ragam untuk mendapatkan penduga ragam galat dan uji signifikasi untuk mengetahui ada tidaknya pengaruh antar perlakuan. Kesamaan ragam diuji dengan uji Bartlett dan kemenambahan data diuji dengan uji Tuckey. Untuk mengetahui perbedaan antar perlakuan, data dianalisis lebih lanjut menggunakan uji Beda Nyata Jujur (BNJ) pada taraf $5 \%$.

Pembuatan Pati Garut. Umbi garut dikupas, digiling, ditambah air dengan perbandingan 9:1 (v/w), diremas dan disaring, kemudian pati garut diendapkan selama 1-2 jam. Setelah itu, air yang berada di bagian atas endapan dibuang, sedangkan endapannya dicuci menggunakan air, kemudian dikeringkan pada suhu $60^{\circ} \mathrm{C}$ dan digiling untuk mendapatkan pati garut yang halus (Suprihatin 1991).

Pembuatan Tepung Kacang Merah. Kacang merah direndam dalam air selama 7 jam, kemudian kulit ari dikupas. Kacang merah kupas kulit dikeringkan menggunakan oven pada suhu $60^{\circ} \mathrm{C}$ selama 20 jam, digiling dan diayak dengan ayakan 80 mesh sampai diperoleh tepung kacang merah yang halus (Karisma 2014). Menurut Akaerue \& Onwuka (2010), tepung yang diproses tanpa pengupasan kulit lebih cepat menggumpal dibanding tepung dengan pengupasan kulit pada pembuatan tepung kacang hijau. Hasil penelitian 
Astuti, dkk: Sifat Fisik dan Sensori Flakes Pati Garut dan Kacang Merah dengan penambahan ...

Pangastuti et al. (2013) menunjukkan bahwa pengupasan kacang merah meningkatkan kecerahan dan derajat putih, serta menurunkan densitas kamba tepung kacang merah.

Pembuatan Tiwul Singkong. Umbi singkong dikupas kulit, dicuci dan diiris untuk memperkecil ukuran singkong dan mempercepat proses pengeringan. Proses pengeringan dilakukan dengan sinar matahari selama 2-3 hari sampai irisan singkong kering. Singkong yang telah melalui tahap pengeringan disebut gaplek singkong. Selanjutnya gaplek singkong dicuci dan direndam dalam air selama 2 hari 2 malam. Selama proses perendaman, air diganti setiap pagi dan sore hari, kemudian singkong ditiriskan dan digiling. Setelah itu, air yang terkandung dalam singkong diperas, diayak dan dilakukan pembentukan butiran-butiran dengan diameter 2-3 mm. Setelah itu, butiran-butiran yang dihasilkan dikukus selama 10 menit lalu dikeringkan kembali dengan sinar matahari selama 2 hari hingga diperoleh tiwul singkong (Hasan et al. 2011).

Pembuatan flakes pati garut dan kacang merah dengan penambahan tiwul singkong dilakukan menurut metode Chairil \& Kustiyah (2014) yang dimodifikasi. Pencampuran pati garut dan tepung kacang merah sesuai perlakuan yaitu 100\%: 0\%, 90\%: 10\%, 80\%: 20\%, 70\%:30\%, 60\%: 40\%, dan 50\%: 50\%. Masing-masing formulasi ditambah tiwul singkong sebanyak $40 \mathrm{~g}$. Gula rendah kalori ditambahkan pada adonan flakes sebanyak $11,11 \%$ dari total adonan tepung (pati garut, kacang merah, dan tiwul singkong) yaitu $40 \mathrm{~g}$, garam ditambahkan sebanyak 1,11\% dari total adonan tepung yaitu $2 \mathrm{~g}$, dan air ditambahkan sebanyak 66,66\% dari total adonan tepung yaitu $120 \mathrm{~g}$, sehingga diperoleh total adonan sebanyak $322 \mathrm{~g}$ (Sianturi \& Marliyati 2014) yang dimodifikasi. Formulasi flakes pati garut dan kacang merah dengan penambahan tiwul singkong dapat dilihat pada Tabel 1. Pati garut dan tepung kacang merah dicampur dengan bahan-bahan kering yaitu tiwul singkong, garam, dan gula rendah kalori hingga homogen, ditambah air dan dilakukan pencampuran dengan mixer sampai homogen. Setelah itu, adonan dikukus selama 3 menit pada suhu $70^{\circ} \mathrm{C}$ menggunakan panci pengukus.Setelah pengukusan, dilakukan pembentukan adonan menjadi bulatan, dipipihkan dengan noodle maker ketebalan $0,5 \mathrm{~mm}$, diiris dengan ukuran $1 \mathrm{~cm} \times 1 \mathrm{~cm}$ dan diletakkan di tray, kemudian dipanggang pada suhu $150^{\circ} \mathrm{C}$ selama 15 menit dalam oven pemanggang.

Tabel 1. Formulasi flakes pati garut dan kacang merah dengan penambahan tiwul singkong

\begin{tabular}{lcccccc}
\hline Formulasi & F1 & F2 & F3 & F4 & F5 & F6 \\
\hline Pati garut (g) & 140 & 126 & 112 & 98 & 84 & 70 \\
Tepung kacang merah (g) & 0 & 14 & 28 & 42 & 56 & 70 \\
Tiwul singkong (g) & 40 & 40 & 40 & 40 & 40 & 40 \\
Garam halus (g) & 2 & 2 & 2 & 2 & 2 & 2 \\
Gula rendah kalori (g) & 20 & 20 & 20 & 20 & 20 & 20 \\
Air (g) & 120 & 120 & 120 & 120 & 120 & 120 \\
Total adonan (g) & 322 & 322 & 322 & 322 & 322 & 322 \\
\hline
\end{tabular}

Sumber : Sianturi \& Marliyati (2014) dimodifikasi

Pengamatan bahan baku pati garut, tepung kacang merah dan tiwul singkong meliputi kadar air, kadar abu, kadar protein, kadar lemak, kadar karbohidrat by difference, kadar serat kasar, kadar amilosa dan kadar amilopektin. Pengamatan produk flakes meliputi analisis fisik (tekstur) dengan alat Hardness Tester, uji sensori (tekstur, warna, rasa dan aroma) menggunakan metode skoring, dan penerimaan keseluruhan flakes menggunakan metode hedonik. Analisis terhadap flakes dengan sifat fisik dan sensori terbaik dilakukan terhadap kadar air, kadar abu, kadar protein, kadar lemak, kadar karbohidrat by difference dan kadar serat kasar.

\section{HASIL DAN PEMBAHASAN}

Analisis Kimia Bahan Baku. Komposisi pati garut, tepung kacang merah, dan tiwul singkong sebagai bahan utama flakes dapat dilihat pada Tabel 2. 
Tabel 2. Komposisi pati garut, tepung kacang merah, dan tiwul singkong

\begin{tabular}{lccc}
\hline Komponen (\%) & Pati Garut & Tepung Kacang Merah & Tiwul Singkong \\
\hline Air & 11,82 & 7,53 & 8,20 \\
Abu & 0,37 & 3,52 & 0,57 \\
Protein & 0,06 & 20,10 & 1,06 \\
Lemak & 0,09 & 1,38 & 0,17 \\
Karbohidrat & 87,68 & 67,48 & 90,05 \\
\hline Serat Kasar & 0,06 & 2,60 & 4,63 \\
\hline Pati & 71,87 & 43,05 & 61,23 \\
$\quad$ Amilosa & 41,13 & 15,44 & 27,42 \\
$\quad$ Amilopektin & 30,74 & 27,61 & 33,82 \\
\hline
\end{tabular}

Analisis Fisik Tekstur. Berdasarkan pengujian tekstur dengan alat Hardness-Tester, tingkat kekerasan produk (kgf) merupakan besarnya gaya tekan yang dibutuhkan hingga produk pecah. Semakin renyah produk flakes yang diukur, nilai kekerasan semakin kecil. Sebaliknya, semakin besar nilai kekerasan, flakes semakin keras (Melianawati 1998).

Tabel 3. Perbandingan pati garut dan tepung kacang merah dengan penambahan tiwul singkong terhadap tekstur (kekerasan) flakes

\begin{tabular}{ccc}
\hline Formulasi & $\begin{array}{c}\text { Perbandingan pati garut dan } \\
\text { tepung kacang merah }\end{array}$ & Nilai Tengah \\
\hline F5 & $60: 40$ & $2,16 \mathrm{a}$ \\
F6 & $50: 50$ & $1,47 \mathrm{~b}$ \\
F3 & $80: 20$ & $0,98 \mathrm{bc}$ \\
F4 & $70: 30$ & $0,90 \mathrm{c}$ \\
F1 & $100: 0$ & $0,75 \mathrm{c}$ \\
F2 & $90: 10$ & $0,58 \mathrm{c}$ \\
\hline
\end{tabular}

Keterangan : Angka yang diikuti huruf yang sama berarti tidak berpengaruh nyata pada taraf 5\%

$(\mathrm{BNJ} 0,05=0,539)$

Kadar air menentukan kesegaran, stabilitas, dan keawetan pangan. Kadar air merupakan komponen yang sangat penting karena mempengaruhi penampakan, tekstur dan cita rasa bahan pangan (Kusnandar 2010). Menurut Kusumadewi (2010), kerenyahan pada produk makanan kering dipengaruhi oleh jumlah air yang terikat dalam matriks karbohidrat. Kerenyahan flakes berhubungan dengan kadar air flakes. Semakin rendah kadar air flakes, maka flakes akan menjadi semakin renyah. Semakin banyak proporsi pati garut yang digunakan dalam pembuatan flakes, kadar air yang terkandung dalam bahan semakin tinggi sehingga tekstur flakes menjadi tidak renyah (nilai kekerasan lebih kecil). Sebaliknya, semakin sedikit proporsi pati garut, tekstur flakesyang dihasilkan akan semakin renyah (nilai kekerasan lebih besar).

Berdasarkan Tabel 2, pati garut mengandung kadar amilosa lebih tinggi dibanding amilopektin. Semakin banyak amilosa yang terkandung pada flakes, flakes semakin keras. Hal ini sejalan dengan Kusnandar (2010) yang menyatakan bahwa pati dengan kandungan amilosa tinggi cenderung menghasilkan produk yang keras. Sebaliknya, produk yang memiliki kandungan amilopektin tinggi bersifat ringan, porous, dan renyah karena amilopektin menyebabkan terjadinya proses pemekaran pada produk. Menurut Moraru \& Kokini (2003), pati dengan kandungan amilopektin tinggi menghasilkan produk yang lebih mengembang dibanding pati yang lebih banyak mengandung amilosa. Hal ini disebabkan pada proses pemasakan, rantai amilosa akan terikat satu sama lain sehingga akan menyebabkan polimer-polimer amilosa sulit tertarik pada saat proses pengembangan dan menyebabkan produk yang diolah dari bahan yang mengandung amilosa tinggi kurang mengembang. Hasil penelitian Gisca \& Rahayuni (2013) menunjukkan bahwa penambahan tepung gembili yang semakin banyak menghasilkan flakes dengan tekstur keras karena terjadi peningkatan kadar amilosa pada produk yang dihasilkan. 
Astuti, dkk: Sifat Fisik dan Sensori Flakes Pati Garut dan Kacang Merah dengan penambahan ...

Menurut Atmadja (2006), protein berperan dalam pengembangan produk dan membuat produk lebih renyah. Kandungan protein yang tinggi membantu kekuatan ikatan antara amilopektin yang terdegradasi atau terpecah dan membentuk pengembangan produk yang mengakibatkan produk menjadi renyah. Protein meningkatkan kemampuan gelasi sehingga membentuk fleksibilitas atau kemampuan protein untuk terdenaturasi dan membentuk jaringan dengan ikatan silang (Oakenfull et al. 1997). Dalam penelitian ini, semakin banyak proporsi kacang merah, nilai kekerasan flakes yang diukur dengan Hardness tester semakin besar (flakes semakin keras). Menurut Kusnandar (2010), protein mengikat air dengan adanya gugus hidrogen yang bersifat hidrofilik. Kandungan protein yang tinggi menurunkan viskositas karena protein dan pati membentuk kompleks dengan permukaan granula sehingga kekuatan gel menjadi rendah (Amalia 2014). Protein yang berikatan dengan pati menyebabkan cookies menjadi keras karena interaksi antara protein dan pati melalui ikatan hidrogen (Hoseney \& Rogers 1994). Kekerasan flakes kemungkinan disebabkan oleh ikatan hidrogen antara gugus amino protein kacang merah dengan gugus hidroksil pati garut sehingga membentuk kompleks. Kadar protein tinggi akan menutupi partikel pati sehingga penyerapan air menjadi terhambat (Permatasari 2007). Penghambatan penyerapan air ke dalam pati tersebut mengakibatkan produk yang dihasilkan menjadi keras.

Proses pemanasan akan meningkatkan kompleksitas reaksi antara pati dan protein. Perubahan thermal pada protein menyebabkan terjadinya denaturasi yang dipercepat dengan keberadaan air. Perubahan thermal menyebabkan pati kehilangan kristalinitas, pengembangan granula, dan keluarnya amilosa dari granula. Granula pecah dan matriks amilosa membentuk gel. Pada saat protein dan pati bertemu, akan terbentuk matriks protein-pati yang stabil melibatkan ikatan hidrogen, ikatan kovalen, dan rantai ionik (Gaonkar \& McPherson 2005).

Kekerasan pada produk flakes yang dihasilkan kemungkinan juga disebabkan oleh kadar serat yang terkandung dalam bahan baku pembuatan flakes. Data pada Tabel 2 menunjukkan bahwa kadar serat kacang merah sebesar 2,60\% lebih tinggi dibanding pati garut sebesar 0,06\%. Semakin banyak proporsi kacang merah yang digunakan dalam pembuatan flakes, kadar serat kasar flakes semakin tinggi (Tabel 3). Menurut Harijono, Susanto \& Ismet (2001), kadar serat kasar menyebabkan turunnya daya serap air dalam granula pati. Daya serap air yang menurun mengakibatkan proses gelatinisasi pati menjadi tidak sempurna dan menyebabkan tekstur menjadi keras. Setiaji (2012) menyatakan bahwa peningkatan kekerasan flakes yang disubstitusi tepung kedelai disebabkan tingginya kadar serat tepung kedelai sehingga flakes menjadi berkurang porositasnya. Menurut Gisca \& Rahayuni (2013), tingginya kadar serat dalam tepung gembili menyebabkan tekstur flakes menjadi kasar. Tamtarini \& Yuwanti (2005) menyatakan bahwa serat sebagai senyawa tidak larut dalam air dan memperkuat jaringan bahan, dalam bahan pangan berfungsi sebagai penguat tekstur. Semakin tinggi kadar serat dalam bahan baku, akan dihasilkan produk dengan tekstur yang lebih kokoh dan kuat sehingga mengakibatkan produk menjadi lebih keras. Pada saat proses pembentukan tekstur, komponen pati, serat dan protein saling berkompetisi mengikat air (Paramita \& Putri 2015).

Uji Sensori Tekstur. Berdasarkan Tabel 4, skor tekstur tertinggi $(4,23)$ dihasilkan oleh flakes dengan perbandingan pati garut 50\% dan tepung kacang merah 50\%. Skor tekstur terendah $(3,58)$ dihasilkan oleh flakes dengan perbandingan pati garut $100 \%$ dan tepung kacang merah $0 \%$. Skor tekstur tertinggi dan terendah masuk dalam kriteria yang sama, yaitu kriteria renyah. Uji BNJ 5\% menunjukkan bahwa perbandingan pati garut dan tepung kacang merah tidak berpengaruh nyata terhadap tekstur flakes melalui pengujian sensori. 
Tabel 4. Perbandingan pati garut dan tepung kacang merah terhadap sensori tekstur flakes dengan penambahan tiwul singkong

\begin{tabular}{cccc}
\hline Formulasi & $\begin{array}{c}\text { Perbandingan pati garut dan tepung } \\
\text { kacang merah }\end{array}$ & Skor & Notasi \\
\hline F6 & $50: 50$ & 4,23 & $\mathrm{a}$ \\
F5 & $60: 40$ & 4,14 & $\mathrm{a}$ \\
F4 & $70: 30$ & 4,08 & $\mathrm{a}$ \\
F3 & $80: 20$ & 3,82 & $\mathrm{a}$ \\
F2 & $90: 10$ & 3,73 & $\mathrm{a}$ \\
F1 & $100: 0$ & 3,58 & $\mathrm{a}$ \\
\hline
\end{tabular}

Keterangan : Angka yang diikuti huruf yang sama berarti tidak berpengaruh nyata pada taraf $5 \%$ $($ BNJ $0,05=0,806)$

Menurut Fellows (2017), tekstur produk flakes meliputi kerenyahan, kemudahan dipatahkan dan konsistensi pada gigitan pertama. Umumnya tekstur yang diinginkan pada produk flakes adalah renyah, garing, tidak mudah hancur namun tidak keras. Kerenyahan suatu produk dinilai berdasarkan kemudahan digigit hingga produk patah (Widyasitoresmi 2010). Edmund \& Lloyd (2001) menyatakan bahwa tekstur suatu pangan dipengaruhi oleh komposisi penyusun bahan baku, derajat gelatinisasi, derajat pengembangan, indeks penyerapan air, suhu, dan waktu pemanggangan.Tekstur bahan menjadi kering dan kasar karena air bebas yang berada di permukaan bahan lebih cepat menguap dibanding air terikat. Tekanan dan panas dari oven menyebabkan air dan komponen volatil pada bahan pangan menguap (Potter \& Hotchkiss 2000). Muchtadi (1996) dalam Astuti et al. (2017) menyatakan bahwa perbandingan kandungan amilosa dan amilopektin dalam pati berpengaruh terhadap kerenyahan suatu produk. Kandungan amilopektin yang tinggi membuat produk menjadi mudah mengembang, sedangkan produk dengan kandungan amilosa tinggi akan lebih rapat, lebih keras, dan kurang mengembang.

Menurut Stanley (1987), hasil scanning electron micrograph terhadap suatu ekstrudat menunjukkan bahwa struktur porous yang berongga disebabkan proses gelatinisasi. Proses gelatinisasi pada umumnya terjadi dalam tiga tahap. Tahap pertama yaitu penyerapan air oleh granula pati sampai batas yang akan mengembang secara lambat, dimana air secara perlahan dan bolak balik berimbibisi ke dalam granula sehingga terjadi pemutusan ikatan hidrogen antara molekul-molekul granula. Tahap kedua, pengembangan granula secara cepat yang karena menyerap air secara cepat sampai kehilangan sifat birefriengence-nya. Tahap terakhir yaitu granula akan pecah jika cukup air dan suhu terus menerus naik sehingga molekul amilosa keluar dari granula (Kusnandar 2010).

Uji Sensori Warna. Skor warna tertinggi $(4,81)$ dihasilkan flakes dengan perbandingan pati garut $100 \%$ dan tepung kacang merah $0 \%$ dengan kriteria putih kecoklatan. Skor warna terendah $(2,67)$ dihasilkan flakes dengan perbandingan pati garut 50\% dan tepung kacang merah 50\% dengan kriteria coklat muda.

Tabel 5. Perbandingan pati garut dan tepung kacang merah terhadap warna flakes dengan penambahan tiwul singkong

\begin{tabular}{cccl}
\hline Formulasi & $\begin{array}{c}\text { Perbandingan pati garut dan tepung } \\
\text { kacang merah }\end{array}$ & Skor & Notasi \\
\hline F1 & $100: 0$ & 4,81 & $\mathrm{a}$ \\
F2 & $90: 10$ & 4,65 & $\mathrm{a}$ \\
F3 & $80: 20$ & 4,33 & $\mathrm{ab}$ \\
F4 & $70: 30$ & 3,79 & $\mathrm{bc}$ \\
F5 & $60: 40$ & 3,33 & $\mathrm{~cd}$ \\
F6 & $50: 50$ & 2,67 & $\mathrm{~d}$ \\
\hline
\end{tabular}

Keterangan : Angka yang diikuti huruf yang sama berarti tidak berbeda nyata pada taraf $5 \%$ $(\mathrm{BNJ} 0,05=0,7000)$ 
Astuti, dkk: Sifat Fisik dan Sensori Flakes Pati Garut dan Kacang Merah dengan penambahan ...

Penambahan tepung kacang merah mempengaruhi warna flakes yang dihasilkan karena tepung kacang merah memiliki warna putih kekuningan. Penurunan kecerahan warna flakes diduga karena proses pemanggangan yang mengakibatkan terjadinya reaksi Maillard. Menurut Kusnandar (2010), reaksi Maillard terjadi antara gula pereduksi dengan gugus amin bebas dari asam amino, bagian protein atau senyawa lain yang mengandung gugus amin. Pada reaksi Maillard terjadi perubahan hidroksimetil furfural menjadi furfural dan berpolimerasi membentuk senyawa melanoidin yang berwarna coklat (Damodaran et al. 2008). Semakin banyak proporsi tepung kacang merah dalam pembuatan flakes, kadar protein semakin tinggi sehingga menghasilkan produk yang semakin berwarna coklat.

Uji Sensori Rasa dan Aroma. Skor rasa dan aroma tertinggi $(3,50)$ dihasilkan oleh flakes dengan perbandingan pati garut $60 \%$ dan tepung kacang merah $40 \%$ dengan kriteria tidak berasa langu. Skor rasa dan aroma terendah $(3,25)$ dihasilkan oleh flakes dengan perbandingan pati garut $80 \%$ dan tepung kacang merah $20 \%$ dengan kriteria agak berasa langu (Tabel 6).

Tabel 6. Perbandingan pati garut dan tepung kacang merah terhadap rasa dan aroma flakesdengan penambahan tiwul singkong

\begin{tabular}{cccl}
\hline Formulasi & $\begin{array}{c}\text { Perbandingan pati garut dan tepung kacang } \\
\text { merah }\end{array}$ & Skor & Notasi \\
\hline F5 & $60: 40$ & 3,50 & $\mathrm{a}$ \\
F6 & $50: 50$ & 3,47 & $\mathrm{ab}$ \\
F4 & $70: 30$ & 3,28 & $\mathrm{bc}$ \\
F2 & $90: 10$ & 3,28 & $\mathrm{bc}$ \\
F1 & $100: 0$ & 3,28 & $\mathrm{bc}$ \\
F3 & $80: 20$ & 3,25 & $\mathrm{c}$ \\
\hline
\end{tabular}

Keterangan : Angka yang diikuti huruf yang sama berarti tidak berbeda nyata pada taraf 5\% (BNJ 0,05=0,218)

Menurut Muchtadi \& Sugiyono (1996), rasa dan aroma langu disebabkan oleh aktivitas enzim lipoksigenase yang secara alami terdapat dalam kacang-kacangan. Enzim lipoksigenase akan menghidrolisis lemak kacang dan menghasilkan senyawa heksanol yang menimbulkan rasa dan aroma langu. Rasa dan aroma langu dapat dihilangkan dengan inaktifasi enzim lipoksigenase melalui pemanasan (Muchtadi \& Sugiyono 1996). Hasil penelitian Karisma (2014) menunjukkan bahwa tepung kacang merah mengandung asam glutamat dan asam aspartat yang merupakan asam amino non-essensial masing-masing sebesar 2,29g/100g protein dan $4,05 \mathrm{~g} / 100 \mathrm{~g}$ protein, sedangkan asam amino essensial yang terdapat dalam jumlah tinggi adalah asam amino leusin dan lisin masing-masing sebesar $2,10 \mathrm{~g} / 100 \mathrm{~g}$ protein dan $1,83 \mathrm{~g} / 100 \mathrm{~g}$ protein. Hal ini sejalan dengan pernyataan Astawan (2009) bahwa kacang merah memiliki kandungan asam amino leusin dan lisin yang cukup banyak. Kandungan asam amino pada kacang merah berperan dalam meningkatkan rasa dan aroma flakes, sehingga skor rasa dan aroma flakes mendapat penilaian panelis yang semakin tinggi dengan semakin banyak kacang merah yang ditambahkan.

Uji Sensori Penerimaan Keseluruhan. Tabel 7 menunjukkan bahwa skor penerimaan keseluruhan tertinggi sebesar 3,87 dihasilkan flakes dengan perbandingan pati garut 50\% dan tepung kacang merah 50\% dengan kriteria suka. Skor penerimaan keseluruhan terendah $(2,83)$ dengan kriteria agak suka dihasilkan flakes dengan perbandingan pati garut $100 \%$ dan tepung kacang merah $0 \%$.

Penerimaan keseluruhan tertinggi pada formulasi perbandingan pati garut dan tepung kacang merah (50:50) sebesar 3,87 (kriteria suka) didukung oleh pengujian skoring yang menghasilkan tekstur flakes renyah, warna coklat muda,serta rasa dan aroma agak berasa langu. Rasa dan aroma agak berasa langu disebabkan kacang merah mengandung enzim lipoksigenase. Penerimaan keseluruhan formulasi perbandingan pati garut dan tepung kacang merah (60:40) tidak berbeda dengan formulasi perbandingan pati garut dan tepung kacang merah (50:50), namun skor perbandingan pati garut dan tepung kacang merah (50:50) lebih tinggi dibanding perbandingan pati garut dan tepung kacang merah (60:40). 
Tabel 7. Pengaruh perbandingan pati garut dan tepung kacang merah terhadap penerimaan keseluruhan flakes dengan penambahan tiwul singkong

\begin{tabular}{cccl}
\hline Formulasi & $\begin{array}{c}\text { Perbandingan pati garut dan tepung } \\
\text { kacang merah }\end{array}$ & Skor & Notasi \\
\hline F6 & $50: 50$ & 3,87 & $\mathrm{a}$ \\
F5 & $60: 40$ & 3,75 & $\mathrm{ab}$ \\
F4 & $70: 30$ & 3,71 & $\mathrm{ab}$ \\
F3 & $80: 20$ & 3,54 & $\mathrm{~b}$ \\
F2 & $90: 10$ & 3,18 & $\mathrm{c}$ \\
F1 & $100: 0$ & 2,83 & $\mathrm{~d}$ \\
\hline
\end{tabular}

Keterangan : Angka yang diikuti huruf yang sama berarti tidak berpengaruh nyata pada taraf $5 \%$ $(\mathrm{BNJ} 0,05=0,306)$

Penentuan Formulasi Terbaik. Penentuan perbandingan pati garut dan tepung kacang merah terbaik diperoleh berdasarkan hasil analisis fisik dan uji sensori flakes. Flakes dengan formulasi terbaik pada pengujian sensori diharapkan memiliki kriteria tekstur renyah, warna coklat muda, rasa dan aroma tidak berasa langu, serta penerimaan keseluruhan disukai panelis.

Tabel 8. Penentuan formulasi flakes pati garut dan kacang merah dengan penambahan tiwul singkong yang terbaik

\begin{tabular}{llrllll}
\hline \multicolumn{1}{c}{ Parameter } & F1 & F2 & F3 & F4 & F5 & F6 \\
\hline Tekstur (Kekerasan) & $0,75 \mathrm{c}^{*}$ & $0,58 \mathrm{c}^{*}$ & $0,98 \mathrm{bc}^{*}$ & $0,90 \mathrm{c}^{*}$ & $2,16 \mathrm{a}$ & $1,47 \mathrm{~b}$ \\
Tekstur (Sensori) & $3,58 \mathrm{a}^{*}$ & $3,73 \mathrm{a}^{*}$ & $3,82 \mathrm{a}^{*}$ & $4,08 \mathrm{a}^{*}$ & $4,14 \mathrm{a}^{*}$ & $4,23 \mathrm{a}^{*}$ \\
Warna & $4,81 \mathrm{a}$ & $4,65 \mathrm{a}$ & $4,33 \mathrm{ab}$ & $3,79 \mathrm{bc}$ & $3,33 \mathrm{~cd}^{*}$ & $2,67 \mathrm{~d}^{*}$ \\
Rasa dan aroma & $3,28 \mathrm{~b}$ & $3,28 \mathrm{~b}$ & $3,25 \mathrm{~b}$ & $3,28 \mathrm{~b}$ & $3,50 \mathrm{a}^{*}$ & $3,47 \mathrm{ab}^{*}$ \\
Penerimaan keseluruhan & $2,83 \mathrm{~d}$ & $3,18 \mathrm{c}$ & $3,54 \mathrm{~b}$ & $3,71 \mathrm{ab} *$ & $3,75 \mathrm{ab}^{*}$ & $3,87 \mathrm{a}^{*}$ \\
\hline$\Sigma(*)$ & 2 & 2 & 1 & 3 & 4 & 4 \\
\hline
\end{tabular}

\section{Keterangan :}

$\mathrm{F} 1=$ Pati garut $100 \%:$ Kacang merah $0 \%$

F2 = Pati garut $90 \%$ : Kacang merah $10 \%$

F3 = Pati garut $80 \%$ : Kacang merah $20 \%$

F4 = Pati garut $70 \%$ : Kacang merah $30 \%$

F5 = Pati garut $60 \%$ : Kacang merah $40 \%$

F6 = Pati garut $50 \%$ : Kacang merah $50 \%$

$*=$ Formulasi terbaik pada parameter tersebut

Tabel 8 menunjukkan bahwa flakes dengan formulasi F5 (60\% pati garut dan 40\% tepung kacang merah) dan formulasi F6 (50\% pati garut dan 50\% tepung kacang merah) memiliki skor rata-rata yang tidak berbeda nyata pada setiap parameter pengujian sensori. Jumlah parameter terbaik (tanda*) pada formulasi F5 dan F6 masing-masing sebanyak 4 parameter. Pada penilaian tekstur, kedua formulasi menghasilkan tekstur flakes yang tidak berbeda nyata dengan kriteria renyah. Akan tetapi, flakes formulasi F6 memiliki skor tekstur $(4,23)$ yang lebih tinggi dibanding formulasi F5 dengan skor 4,14. Kedua formulasi memiliki skor warna 3 dengan kriteria warna coklat muda dan kriteria rasa dan aroma berasa agak langu. Pada parameter penerimaan keseluruhan, skor formulasi F6 sebesar 3,87 (suka) lebih tinggi dari formulasi F5 sebesar 3,75 (suka). Formulasi F5 berbeda dengan formulasi F6 pada parameter teksur berdasarkan pengujian fisik (kekerasan). Tekstur flakes formulasi F6 sebesar 1,47 kgf lebih rendah dibanding formulasi F5 sebesar 2,16 Kgf. Hasil tersebut menunjukkan bahwa formulasi F6 menghasilkan flakes dengan tekstur yang lebih baik dibanding formulasi F5 karena semakin kecil nilai tekstur, flakes semakin tidak keras.

Harga pati garut lebih mahal dibanding tepung kacang merah. Flakes formulasi F6 menggunakan pati garut dalam jumlah yang lebih sedikit dibanding formulasi F5. Berdasarkan segi ekonomis, formulasi F6 dipilih sebagai formulasi terbaik karena menghasilkan flakes yang tidak berbeda dengan formulasi F5, namun lebih efisien dalam penggunaan bahan baku. Oleh karena itu, flakes dengan perbandingan pati garut 50\% dan 
Astuti, dkk: Sifat Fisik dan Sensori Flakes Pati Garut dan Kacang Merah dengan penambahan ...

tepung kacang merah 50\% (F6) merupakan formulasi terbaik yang menghasilkan flakes dengan skor tekstur (sensori) sebesar 4,23(renyah), warna sebesar 2,67 (coklat muda), rasa dan aroma sebesar 3,47 (tidak berasa langu), dan penerimaan keseluruhan sebesar 3,87 (suka).

Komposisi Kimia Flakes Formulasi Terbaik. Hasil pengujian analisis kimia flakes formulasi terbaik ( F6) pada Tabel 9 menunjukkan bahwa kadar air flakes formulasi terbaik sebesar 5,17\% lebih tinggi dibanding kadar air SNI Sereal (SNI 01-4270-1996) yaitu maksimal 3\%. Perbedaan bahan baku yang digunakan pada pembuatan flakes dan sereal standar menghasilkan kadar air yang berbeda. Kadar serat kasar flakes formulasi terbaik di atas batas maksimal kadar serat kasar menurut SNI yaitu maksimal 0,7\%. Kadar serat kasar flakes dipengaruhi kadar serat kasar bahan baku tepung kacang merah dan tiwul singkong yang cukup tinggi, masingmasing sebesar 2,60\% dan 4,63\% (Tabel 1).

Tabel 9. Komposisi kimia flakes formulasi terbaik

\begin{tabular}{|c|c|c|}
\hline Komponen & Jumlah (\%) & SNI Sereal \\
\hline Air & 5,17 & Maks.3\% \\
\hline $\mathrm{Abu}$ & 2,81 & Maks.4\% \\
\hline Protein & 11,53 & Min.5\% \\
\hline Lemak & 1,25 & Min. 7\% \\
\hline Karbohidrat & 79,24 & Min. $60,7 \%$ \\
\hline Serat Kasar & 2,55 & Maks. $0,7 \%$ \\
\hline
\end{tabular}

\section{KESIMPULAN}

Formulasi F6 (50\% pati garut dan 50\% kacang merah) merupakan formula flakes terbaik yang menghasilkan sifat fisik tekstur sebesar 1,47 kgf, sifat sensori tekstur dengan skor 4,32 (renyah), skor warna sebesar 2,67 (coklat muda), skor rasa dan aroma sebesar 3,47 (agak berasa langu), dan skor penerimaan keseluruhan sebesar 3,87 (suka). Flakes formulasi terbaik memiliki kadar air sebesar 5,17\%, kadar abu sebesar 2,81\%, kadar protein sebesar 11,53\%, kadar lemak sebesar 1,25\%, kadar karbohidrat sebesar 79,24\%, dan kadar serat kasar sebesar 2,55\%.

\section{DAFTAR PUSTAKA}

Amalia, R. 2014. Karakteristik Fisikokimia dan Fungsional Tepung Komposit Berbahan Dasar Beras, Ubi Jalar, Kentang, Kedelai, dan Xanthan Gum. (Skripsi). Medan: Universitas Sumatera Utara.

Akaerue, B.I. \& Onwuka, G.I. 2010. Evaluation of the yield, protein content and functional properties of mungbean (Vigna radiata (L.) wilczek) protein isolates as affected by processing. Pakistan Journal of Nutrition, 9(8), pp. 728-735. Available at : DOI: 10.3923/pjn.2010.728.735

Astawan, M. 2009. Kacang Hijau. Sehat dengan Hidangan Kacang dan Biji-Bijian. Jakarta: Penebar Swadaya.

Astuti, S., Suharyono, A.S \& Fitra, N. 2017. Pengaruh formulasi jamur tiram putih (pleurotus oestreatus) dan tapioka terhadap sifat fisik, organoleptik, dan kimia kerupuk. Jurnal Penelitian Pertanian Terapan, 16(3), pp. 163-173. Available at : https://doi.org/10.25181/jppt.v16i3.94

Atmadja, G. S. 2006. Pengembangan Produk Pangan Berbahan Dasar Jagung Quality Protein Maize (Zea mays L.) dengan Menggunakan Teknologi Ekstrusi (Skripsi). Bogor: Institut Pertanian Bogor.

Chairil, M.M.F. \& Kustiyah, L. 2014. Formulasi flakes berbasis pati garut dengan fortifikasi zat besi (fe) untuk perbaikan status besi remaja putri. Jurnal Gizi dan Pangan, 9(2), pp. 89-96. Available at : https://doi.org/10.25182/jgp.2014.9.2. 
Jurnal Penelitian Pertanian Terapan

Damodaran, S., Parkin, K.L. \& Fennema, O.R. 2008. Fennema's Food Chemistry. Fourth Ed. Boca Raton : CRC Press.

Edmund, W.L. \& Lloyd, W. 2001. Snacks Food Processing. New York: CRC Press.

Fellows, P. J. 2017. Processing by removal of heat. In: Food Processing Technology: Principles and Practice. Fourth Ed. Elsevier Ltd. https://doi.org/10.1016/b978-0-08-100522-4.00044-4

Gaonkar, A.G. \& McPherson, A. 2005. Ingredient Interactions Effects on Food Quality. Second Ed. Boca Raton, Florida: CRC Press.

Gisca, B.I.D. \& Rahayuni, A. 2013. Penambahan gembili pada flakes jewawut ikan gabus sebagai

alternatif makanan tambahan anak gizi kurang. Journal of Nutrition College, 2(4), pp.505-513. Available at : https://doi.org/10.14710/jnc.v2i4.3733

Harijono, Susanto, W.H. \& Ismet, F. 2001. Studi penggunaan proporsi tepung (sorghum ketan dengan beras ketan) dan tingkat kepekatan santan yang berbeda terhadap kualitas kue semprong. Jurnal Teknologi Pertanian, 2(1), pp. 1-11. Available at : https://jtp.ub.ac.id/index.php/jtp/article/view/114/461

Hasan, V., Astuti, S., \& Susilawati. 2011. Indeks glikemik oyek dan tiwul dari umbi garut (Marantha arundinaceae L.), suweg (Amorphallus campanullatus) dan singkong (Manihot utilisima). Jurnal Teknologi \& Industri Hasil Pertanian, 16, pp. 34-50.

Hoseney R.C. \& Rogers, D. 1994. Mechanism of Sugar Functionality in Cookies : The Science of Cookie and Cracker Production. American Association of Cereal Chemists. St. Paul. MN.

Karisma, V. 2014. Pengaruh Penepungan, Perebusan, Perendaman Asam, dan Fermentasi terhadap Komposisi Kimia Kacang Merah (Phaseolus vulgaris L.) (Skripsi). Bogor: Institut Pertanian Bogor.

Kusnandar, F. 2010. Kimia Pangan : Komponen Makro. Jakarta: Dian Rakyat.

Kusumadewi, D. 2010. Karakterisasi Produk Ekstrusi dari Campuran Jagung, Umbi Ganyong, dan Umbi Garut [Tesis]. Bogor: Institut Pertanian Bogor.

Mariati. 2001. Karakterisasi Sifat Fisikokimia Pati dan Tepung Garut (Maranta arundinaceae L.) dari Beberapa Varietas Lokal (Skripsi). Bogor: Institut Pertanian Bogor.

Melianawati, A. 1998. Karakteristik Produk Ekstrusi Campuran Menir Beras-Tepung Pisang-Kedelai Olahan (Skripsi). Bogor: Institut Pertanian Bogor.

Moraru, C. I. \& J. L. Kokini. 2003. Nucleation and expansion during extrusion and microwave heating of cereal foods. Comprehensive Reviews in Food Science and Food Safety, 2, pp. 147-165. Available at : https://onlinelibrary.wiley.com/doi/epdf/10.1111/j.1541-4337.2003.tb00020.x

Muchtadi, T. R. \& Sugiyono. 1996. Ilmu Pengetahuan Bahan Pangan. PAU Pangan dan Gizi. Bogor: Institut Pertanian Bogor.

Oakenfull, D.J., Pearce, R. W. \& Burley. 1997. Protein gelation. In: Pamodaran, S. \& A. Paraf (ed). Food Protein and Their Application. New York : Marcel Dekker.

Pangastuti, H.E, Affandi, D.R., \& Ishartani, D. 2013. Karakterisasi sifat fisik dan kimia tepung kacang merah (Phaseolus vulgaris L.) dengan beberapa perlakuan pendahuluan. Jurnal Teknosains Pangan, 2(1), pp. 20-29. Available at : http:www.ilmupangan.fp.uns.ac.id 
Astuti, dkk: Sifat Fisik dan Sensori Flakes Pati Garut dan Kacang Merah dengan penambahan ...

Paramita, A. H. \& Putri, W.D.R. 2015. Pengaruh penambahan tepung bengkuang dan lama pengukusan terhadap karakteristik fisik, kimia, dan organoleptik flake talas. Jurnal Pangan dan Agroindustri, 3(3), pp. 1071-1082.

Permatasari, N. 2007. Karakterisasi Pati Jagung Varietas Unggul Nasional (Skripsi). Bogor: Institut Pertanian Bogor.

Potter \& Hotchkiss. 2000. Book reviews : Ciencia de los Alimentos. N.N. Potter y J.H. Hotchkiss. $5^{\text {a }}$ edición, traducido del inglés al castellano por Bernabé Sanz Pérez et al. Publicado en 1999 por Editorial Acribia, S.A. XI + 667 pp., ISBN 8420008591 5. Food Science and Technology International. Available at : https://doi.org/10.1177/108201320000600213

Setiaji, B. 2012. Pengaruh Suhu dan Lama Pemanggangan terhadap Karakteristik Soyflakes (Glycine max L) (Skripsi). Bandung: Universitas Pasundan.

Sianturi, D. P. \& Marliyati, S.A. 2014. Formulasi flakes tepung komposit pati garut dan tepung singkong dengan penambahan pegagan sebagai pangan fungsional sarapan anak Sekolah Dasar. Jurnal Gizi dan Pangan, 9(1), pp. 15-22. Available at : https://doi.org/10.25182/jgp.2014.9.1.\%25p

Stanley, D. 1987. Food texture and microstructure. In : Moskowwitz, H.R (ed). Food Texture : Instrumental and Sensory Measurement. New York: Marcel Dekker.

Suprihatin, C. 1991. Pemanfaatan Tepung Pati Garut (Maranta arundinaceae Linn.) sebagai Bahan Makanan Tambahan Anak Balita (Skripsi). Bogor: Institut Pertanian Bogor.

Tamtarini \& Yuwanti, S. 2005. Pengaruh penambahan koro-koroan terhadap sifat fisik dan sensori flakes ubi jalar. Jurnal Teknologi Pertanian, 6(3), pp. 187-192.

Vijayakumar, P.T \& Mohankumar, J.B. 2009. Formulation and characterization of millet flour blend incorporated composite flour. International Journal of Agriculture Sciences, 1(2), pp. 46-54.

Widyasitoresmi, H. 2010. Formulasi dan Karakterisasi Flake Berbasis Sorgum (Sorghum bicolor L.) dan Ubi Jalar Ungu (Ipomoea batatas L.) (Skripsi). Bogor: Institut Pertanian Bogor. 